\title{
Micrometric evaluation of two botanical source plants of Guduchi i.e. Tinospora cordifolia (Wild.) Miers and Tinospora malabarica (Lam.) Hook. f. \& Thomson stem and leaf
}

Research Article

\section{Anu Joy ${ }^{*}$, Harisha C R ${ }^{2}$, Acharya R N ${ }^{3}$}

\author{
1. PG. Scholar, Dravyaguna Department, 2. Professor, Head of Pharmacognosy Department, \\ 3. Professor \& Head of Dravyaguna Department, \\ ITRA, Jamnagar.
}

\begin{abstract}
Background: Guduchi, also known as an Amrita, is one of the important medicinal plants used in Ayurveda. Though Tinospora cordifolia (Wild.) Miers, considered as the official botanical source plant of Guduchi other two species such as Tinospora malabarica (Lam.) Hook. f. \& Thomson and Tinospora crispa (L.) Hook. f. \& Thomson are also used as a source plant in different parts of India. Though it looks very similar in morphological characters, the micrometric differentiation of two species that is T. cordifolia and T. malabarica are still lacking. Aim: To differentiate the two species of Tinospora through micrometric analysis. Materials and methods: This study portrays both authenticate fresh stem and leaf and with their powdered samples standard histochemical materials, and other laboratory equipment. Result: T. cordifolia and T. malabarica are deciduous woody climbers. The Habitats of both plants are different. T. cordifolia having more prominent lenticels than that of T. malabarica. Main differentiating feature present in the leaf is the presence of trichomes. Most abundant uniseriate trichomes are present in $T$. malabarica. Trichomes are absent in T. cordifolia. Conclusion: Present data may encourage researchers to use the various dimensions of the research to flourish the different species of Guduchi.
\end{abstract}

Key Words: Guduchi, Menispermaceae, Pharmacognosy, Surface study, Histo-chemical, Stomatal index.

\section{Introduction}

Ayurveda recommends Guduchi as one of the main drugs of choice in the management of COVID 19 due to its immunomodulatory activities (1). Ayurvedic pharmacopoeia recomments Tinospora cordifolia as the botanical source of Guduchi (2) but in traditionally different species of Tinospora such as, T. malabarica and $T$. crispa are used as the alternatives botanical source of Guduchi (3). Pharmacognostical characters (macro and microscopic) of T.cordifolia, T. malabarica, T. crispa have been reported (4). Through all these three Tinospora species are but $T$. cordifolia and $T$. malabarica are commonly used in different parts of India as botanical sources of Guduchi. T. cordifolia distributed through the tropical Indian subcontinent and China (5). T. malabarica is abundantly seen in South India especially at Konkan, Karnataka, Tamilnadu, Kerala, Odisha and Bengal. T. cordifolia is an extensive climber with corky, grooved bark with adventitious aerial roots. T. malabarica is a giant deciduous climber. It is mixed as adulterant or substituted with $T$. cordifolia

* Corresponding Author:

\section{Anu Joy}

PG scholar,

Department of Dravyaguna,

ITRA, Jamnagar.

Gujarat. India.

Email Id: emailtoanujoy@gmail.com
(6). The present study deals with comparative pharmacognostical along with micrometric evaluation of both $T$. cordifolia and T. malabarica.

\section{Materials and methods \\ Collection of plant material}

T. cordifolia was collected from Jamnagar, Gujarat. T. malabarica collected from Malappuram, Kerala. The whole plant with leaves collected in February. Matured leaves were separated from the plant and stems were cut into pieces. Then both stem and leaves were individually shade dried, coarsely powdered through a mechanical grinder and stored in an airtight glass container for further study.

\section{Macroscopic and Microscopic evaluation}

Both the plants were macroscopically studied with naked eyes. Free hand transverse sections of leaves and stems were taken and examined. Organoleptic parameters such as size, shape, color, odour and taste of all the respective parts ( stem and leaf) of both the plants were observed and recorded. Microscopical examination of all the plant parts were carried out with and without staining. Microphotographs were taken using Carl Zeiss trinocular microscope (7).

\section{Micrometric study}

Microscopical measurements like dimension of the starch grain, length and width of stomata of both $T$. cordifolia and T.malabarica were carried out using 
micrometer with the help of compound microscope Carl Zeiss trinocular microscope (8).

\section{Histochemical}

Histochemical Analysis of stem and leaf powder were treated with respective reagents such as phloroglucinol $+\mathrm{HCl}$, Iodine and Ruthenium red for the detection of lignin, starch and mucilage content respectively in the plant tissues (9).

\section{Surface study}

Surface study was carried out to determine, stomatal number, stomatal index and size of the stomata (10).

\section{Results}

\section{Macroscopy evaluation}

Morphologically, the two species of Tinospora have some differences. Both $T$. cordifolia and $T$. malabarica is a deciduous woody climber, extensively spreading, and grows on a wide range of hedges and trees.

\section{Stem}

Stem of $T$. cordifolia is seriate when young, often with scattered lenticels. Sometimes it has aerial roots and bark is corky, flaking off with age. Average size of the internode of $T$. cordifolia is $7.17 \mathrm{~cm}$. Colour of the stem is greenish with ash colour papery covering and has more prominent lenticels than that of $T$. malabarica.In $T$. malabarica the average length between two nodes, that is an internode, is $5 \mathrm{~cm}$. Stem of $T$. malabarica does not have many lenticels when compared to $T$. cordifolia. The outer papery coating is golden brown in colour. (Table 2: 1-2)

\section{Leaves}

Leaves of $T$. cordifolia are cordate in shape, sinuate at base, glabrous, petioles pulvinate, basal nerves 5-7 in number. In $T$. cordifolia leaf size with petiole is $10-12 \mathrm{~cm} \times 10 \mathrm{~cm}$. Petiole measures $5 \mathrm{~cm}$ In T. malabarica leaves are thin and cordate in shape. Petiole is not much pulvinus. Surface of the leaves of $T$. malabarica contains thin pubescent hairs. On both surfaces of the leaf is parrot green in colour. Nerves on leaves starting from the base of the petiole. Size of leaf without petiole is $7.5 \mathrm{~cm} \mathrm{X} 12.5 \mathrm{~cm}$ and with petiole is $7.9 \mathrm{~cm}$ X $12.5 \mathrm{~cm}$.( Table 2: 3-4)

\section{Microscopical evaluation}

Microscopical and histochemical evaluation shows certain variations in both the species.

\section{Transverse section of Stem}

Stem of the $T$. malabarica section measures $5 \mu \mathrm{m}$ in radius, circular in outline and most abundant uniseriate trichomes are present. Free hand transverse section with 2-3 drops of chloral hydrate solution was examined under a 40x microscope. In T. malabarica starch grains are simple and average size is $0.5 \mu \mathrm{m} \mathrm{X}$ $0.57 \mu \mathrm{m}$. Cork cells contain 5-6 layers. Cortex immediately after cork, made up of 10-12 layers of oval to tear shaped chlorenchymatous and parenchymatous cells. Pericycle rings like structures made of sclerenchymatous cells and having 5-7 layers. Endodermis and pericycle is a single layer which is reddish in colour. Pericyclic fibers are $0.2 \mu \mathrm{m}$ at $10 \mathrm{x}$ microscope. Pericycle ring followed by phloem, cambium and xylem having 5-8 components which are facing towards the central pith. Xylem and xylem components are filled with starch grains. Pith is large and formed by parenchymatous cells loaded with starch grains. Medullary rays are multiseriate and enriched by starch grains. (Plate no: $1 ; 1-4$ )

Transverse section of the $T$. cordifolia stem is cylindrical in shape, slender, wedge shaped and trichomes are absent. Cork cells contain 10-15 layers. Cortex is reduced. Chlorenchyma cells layers are very less. Concentration of starch grains when compared with $T$. malabarica is more in T. cordifolia. Pith is large as compared to T. malabarica. Xylem components are more when compared to T. malabarica. Xylem contains 10-13 components. 11-12 layers of Pericyclic fibers are present. Endodermis have a single layer. In $T$. cordifolia starch grains are large, simple, and oval to tear shaped. Average size of starch grains are $0.44 \mu \mathrm{m} \mathrm{X} 0.54 \mu \mathrm{m}$. Starch grains present in xylem and medullary rays. Starch grains are less in the outer cortical region but the inner cortical region is more loaded with starch grains. Starch grains are more concentrated to the inner cortex, medullary rays and pith.(Plate no: 2;1-5) (Table 2: 5 -12)

\section{Powder microscopy of stem}

T. malabarica stem is creamish grey in colour with woody odour, Bitter astringent taste, coarse texture. Diagnostic characters of T. malabarica stem powder shows cork in surface view, simple starch grain, oil globules, brown content, fragments of pericyclic fiber which are made up of collenchymatous cells, bordered pitted vessels, single fibers, parenchyma cells with starch grain, lignified stone cells.( Plate no: $3 ; 1-10)$

Powder of $T$. cordifolia stem having brownish grey colour, characteristic pungent odour, and Bitter taste, and coarse texture. Powder microscopy shows border pitted vessels and contains both simple and groups of starch grains. Lignified border pitted vessels and cork cells are also present. (Plate no; 4-1-8) (Table 2: 13-14)

\section{Transverse section of Leaf}

Petiole shows more or less the same anatomy of the stem. Diagrammatic section of T. malabarica shows that upper and lower epidermis followed by collenchyma, ground tissue and vascular bundle in midrib and epidermis followed by palisade and spongy parenchyma in lamina. Ample amount of simple, multicellular trichomes with the size of $3.9 \mu \mathrm{m} \times 2 \mu \mathrm{m}$ was found all over the section (Plate no: 5;1-4, Plate no: $7 ; 1-3)$.

Petiole of the leaf more or less resembles the stem except for cork and without any starch grains. Diagrammatic section of $T$. cordifolia shows that the 
leaf contains epidermis with a cuticle. anomocytic stomata having size of $9.6 \mu \mathrm{m}$ X $6.4 \mu \mathrm{m}$. The main differentiating point between $T$. cordifolia and $T$. malabarica is that $T$. cordifolia does not contain trichomes. (Plate no: 6;1-3, Plate no: 8;1-4) (Table 2: 15-18)

\section{Powder microscopy of Leaf}

Organoleptic characters of $T$. malabarica leaf powder are greenish brown in colour, slight aromatic in smell, bitter in taste, with coarse texture and fibrous appearance. Diagnostic characters of leaf powder show fragments of stomata, spiral vessels, spongy parenchyma cells, palisade parenchyma cells, epidermal cells, trichomes, simple fibers etc. (Plate no: 9;1-6)

Colour of T. cordifolia leaf powder is green, having a pungent odour, bitter taste, and texture is fine to coarse powder. It contains simple fibers. Fragments of palisade parenchyma and spongy parenchyma are present. Epidermal cells are seen. Fragments of stomata present. Segments of annular vessels are also present. (Plate no: 10;1-8) (Table 2: 19-20)

\section{Histochemical study}

Histochemical studies were carried out by taking free hand sections of stem treated with various reagents.( Table 1)

Table 1: Observation of histochemical study

\begin{tabular}{|c|c|c|c|c|c|c|c|}
\hline \multirow[b]{2}{*}{ SN } & \multirow[b]{2}{*}{ Reagent } & \multirow[b]{2}{*}{ Observation } & \multirow[b]{2}{*}{ Characteristic } & \multicolumn{2}{|c|}{ T.cordifolia } & \multicolumn{2}{|c|}{ T.malabarica } \\
\hline & & & & Leaf & Stem & Leaf & Stem \\
\hline 1 & Phloroglucinol + Conc. $\mathrm{HCl}$ & Red & Lignified cells & - & + & - & + \\
\hline 2 & Iodine & Blue & Starch grains & - & + & - & + \\
\hline 3 & Phloroglucinol + Conc. $\mathrm{HCl}$ & Dissolved & Ca Ox crystals & - & - & - & - \\
\hline 4 & Ruthenium & Red & Mucilage & + & + & + & + \\
\hline
\end{tabular}

\section{Surface study}

The TS of the leaf of $T$. cordifolia contains anomocytic stomata having size of $9.6 \mu \mathrm{m}$ X $6.4 \mu \mathrm{m}$. Stomata type of $T$. malabarica is anomocytic and average size is $0.62 \mu \mathrm{m}$ length and $0.56 \mu \mathrm{m}$ breadth. (Plate no: 11;1-4) Palisade ratio and stomata index comes under the surface study. T. cordifolia has a palisade ratio of $1 / 3.6$ and stomatal index is $6.4 \mu \mathrm{m}^{2}$. $T$. malabarica has a Palisade ratio of $1 / 3$ and stomatal index is $20 \mu \mathrm{m}^{2}$. (Plate no: $12 ; 1-3$ )

\section{Micrometric evaluation}

Microscopical measurements like dimension of the starch grain, cork cells, parenchyma cells layers, xylem components, pericyclic fibers, trichome size of both $T$. cordifolia and T. malabarica were carried out and mentioned in Table 2.

Table 2: Showing the differences between T.cordifolia and T.malabarica

\begin{tabular}{|c|c|c|c|}
\hline No & Character & T. cordifolia & T. malabarica \\
\hline 1 & $\begin{array}{l}\text { Macroscopy: Internode } \\
\text { size }\end{array}$ & $\begin{array}{l}\text { Average size of the internode is } 7.17 \\
\mathrm{~cm}\end{array}$ & Average size of internode is $5 \mathrm{~cm}$ \\
\hline 2 & Lenticels & $\begin{array}{l}\text { Colour of the stem is greenish ash and } \\
\text { has more prominent lenticels. }\end{array}$ & $\begin{array}{l}\text { It does not have many lenticels when compared to } \\
\text { T. Cordifolia. }\end{array}$ \\
\hline 3 & Leaf surface & No pubescent hairs. & Surface of the leaves contains thin pubescent hairs. \\
\hline 4 & Petiole & Pulvinate petioles. & Petiole is not much pulvinus. \\
\hline 5 & Microscopical- stem & $\begin{array}{l}\text { The TS of the stem of } T \text {. cordifolia is } \\
\text { cylindrical in shape, slender, wedge } \\
\text { shaped and hairs are absent. }\end{array}$ & $\begin{array}{l}\text { Stem of the } T \text {. malabarica section measures } 5 \mu \mathrm{m} \text { in } \\
\text { radius, circular in outline and most abundant } \\
\text { uniseriate trichomes are present. }\end{array}$ \\
\hline 6 & Starch grains & $\begin{array}{l}\text { Starch grains are large and simple. } \\
\text { Average size of starch grains is } 0.44 \\
\mu \mathrm{m} \mathrm{X} 0.54 \mu \mathrm{m} .\end{array}$ & $\begin{array}{l}\text { Starch grains are large and simple. Average size is } \\
0.5 \mu \mathrm{m} \mathrm{X} 0.57 \mu \mathrm{m} \text {. }\end{array}$ \\
\hline 7 & Cork cells & Cork cells contain $10-15$ layers. & Cork cells contain 5-6 layers. \\
\hline 8 & Cortex & $\begin{array}{l}\text { Cortex is reduced. Chlorenchyma cells } \\
\text { layers are very less. }\end{array}$ & $\begin{array}{l}\text { Cortex contains chlorenchymatous and } \\
\text { parenchymatous cells having 10-12 layers. }\end{array}$ \\
\hline 9 & Pith & Pith is large than that of T. malabarica & Pith is large \\
\hline 10 & $\begin{array}{l}\text { Concentration of starch } \\
\text { grains }\end{array}$ & More & Less \\
\hline 11 & Xylem components & $\begin{array}{l}\text { Xylem components are more. Xylem } \\
\text { contains } 10-13 \text { components. }\end{array}$ & $\begin{array}{l}\text { Xylem components are less in number. Xylem has } \\
\text { 5-8 components which are facing towards the } \\
\text { centre pitch. }\end{array}$ \\
\hline 12 & Pericyclic fibers & $\begin{array}{l}\text { 11-12 layers of Pericyclic fibers are } \\
\text { present. }\end{array}$ & $\begin{array}{l}\text { Pericycle rings like structures made of } \\
\text { sclerenchymatous cells and having 5-7 layers. }\end{array}$ \\
\hline
\end{tabular}




\begin{tabular}{|c|c|c|c|}
\hline 13 & $\begin{array}{l}\text { Powder microscopy } \\
\text {-stem }\end{array}$ & $\begin{array}{l}\text { Powder of } T \text {. cordifolia stem having } \\
\text { brownish grey colour, characteristic } \\
\text { pungent odour, and bitter in taste, and } \\
\text { texture is coarse powder. }\end{array}$ & $\begin{array}{l}\text { Colour of powder of } T \text {. malabarica stem is } \\
\text { creamish grey having a woody odour, bitter and } \\
\text { astringent in taste, texture is coarse powder. }\end{array}$ \\
\hline 14 & Stone cells & Stone cells not found. & Lignified stone cells present. \\
\hline 15 & Leaf & $\begin{array}{l}\text { The TS of the leaf of T.cordifolia } \\
\text { contains anomocytic stomata having } \\
\text { size of } 9.6 \mu \mathrm{m} \times 6.4 \mu \mathrm{m} \text {. }\end{array}$ & $\begin{array}{l}\text { Stomata type is anomocytic and average size is } \\
0.62 \mu \mathrm{m} \text { length and } 0.56 \mu \mathrm{m} \text { breadth. }\end{array}$ \\
\hline 16 & Trichomes & Not containing Trichomes. & $\begin{array}{l}\text { All parts of the leaf are rich with trichomes. } \\
\text { Trichomes present in } T \text {. malabarica are simple } \\
\text { multicellular and have a size of } 3.9 \mu \mathrm{m} \text { X } 2 \mu \mathrm{m} \text {. }\end{array}$ \\
\hline 17 & Palisade ratio & Palisade ratio is $1 / 3.6$. & Palisade ratio is $1 / 3$. \\
\hline 18 & Stomatal index & Stomatal index is $6.4 \mu \mathrm{m}^{2}$. & Stomatal index is $20 \mu \mathrm{m}^{2}$. \\
\hline 19 & $\begin{array}{l}\text { Powder microscopy } \\
\text {-Leaf }\end{array}$ & Trichomes are absent. & Multicellular candle broad trichomes are present \\
\hline 20 & Fibers & It contains simple fibers. & $\begin{array}{l}\text { Both simple and compound fibers are also present } \\
\text { in powder microscopy of the leaf. }\end{array}$ \\
\hline
\end{tabular}

\section{Discussion}

T. cordifolia and T. malabarica are deciduous woody climbers. Habitat of both plants are different, $T$. cordifolia present throughout India but T. malabarica mainly seen in Konkan region and south India. Macroscopically T. cordifolia shows more prominent lenticels than that of T. malabarica. Petiole of $T$. cordifolia is more pulvinus than that of T. malabarica. Main differentiating feature present in the leaf is the presence of trichomes. Trichomes which prevent the evaporation of chemical constituents and secondary metabolites present in plants. Because of the difference in distribution of habitat, trichomes are present in $T$. malabarica. Ample amounts of simple multicellular trichomes were found in the $T$. malabarica leaf transverse section whereas in case of $T$. cordifolia trichomes were absent. Cork cells are more in $T$. cordifolia than that of T. malabarica. Xylem components are more in T. cordifolia. Surface study shows that $T$. cordifolia having less stomata index is 6 when compared to T. malabarica which is having 20 .

\section{Conclusion}

From our study it can be concluded that both species of Tinospora are having some differentiating characteristics when examined macroscopically and microscopically. This study will help us to differentiate the two species, both in fresh, dry, powder condition under microscope. And this study reveals the detailed micrometric measurements of both species.

Plates

Plate 1: Stem of T. malabarica

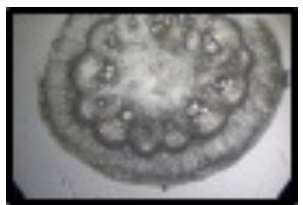

1.Section with epidermis cortex and vascular bundle

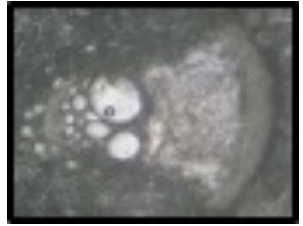

2. Pericyclic fibres, phloem and xylem

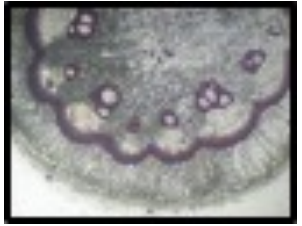

3. Lignified elements of vascular bundle



4. Iodine stained starch grains

Plate 2: Stem of T. cordifolia

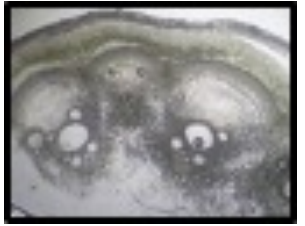

1.Section with epidermis cortex and vascular bundle
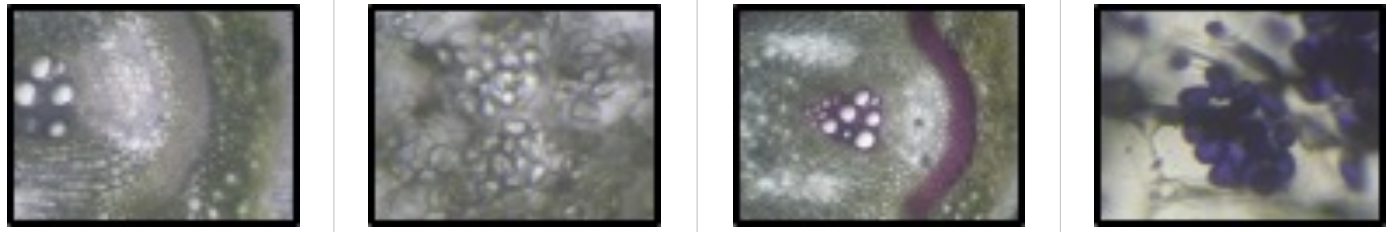

2.Pericyclic fibres, phloem and xylem
3.Parenchyma cells with starch grains
4.Lignified elements of vascular bundle
5.Iodine stained starch grains 
Plate 3: Powder microscopy of stem of $T$. malabarica

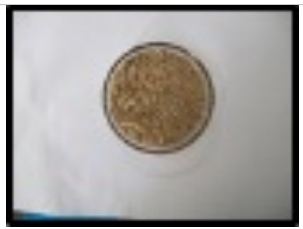

1.Powder as such

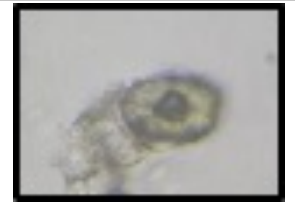

6.Stone cells

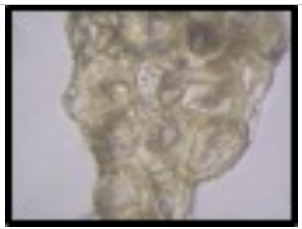

2.Cork in surface view

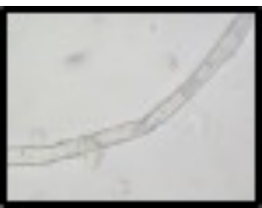

7.Simple fibre

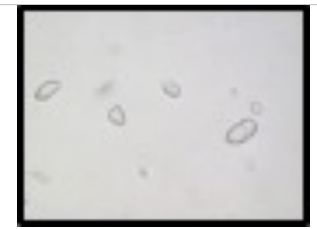

3.Simple starch grains

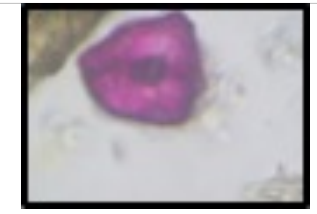

8.Lignified stone cells

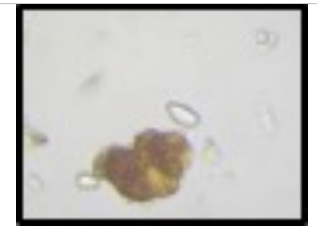

4.Brown content

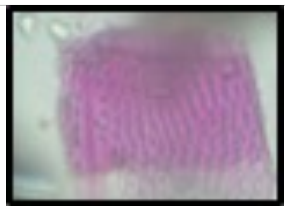

9.Border pitted vessels

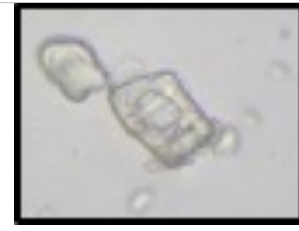

5.Collenchyma cells

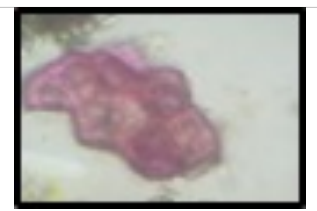

10.Collenchyma cells

Plate 4: Powder microscopy of $T$. cordifolia stem



1.Collenchyma cells

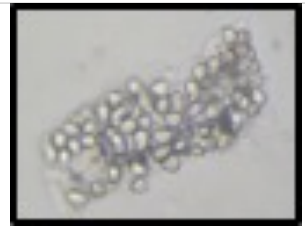

5.Simple starch grains

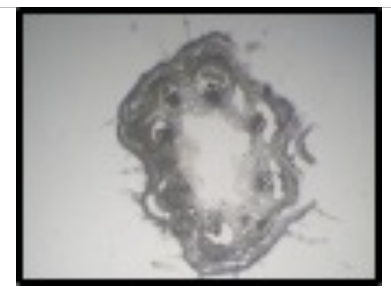

1. Diagrammatic section with epidermis, cortex and vascular bundle

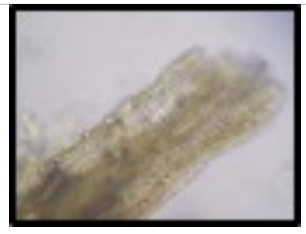

2. Group of fibres

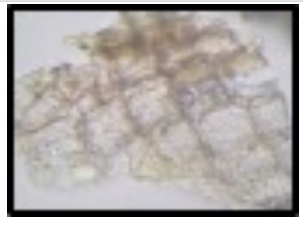

6.Cork in tangential view

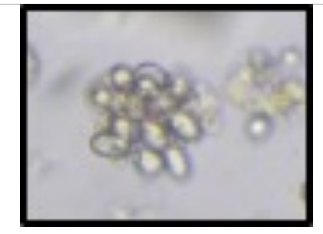

3.Group of starch grains

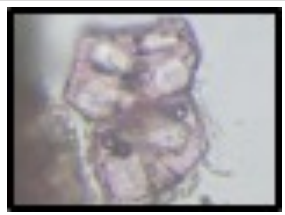

7.Lignified collenchymas cells

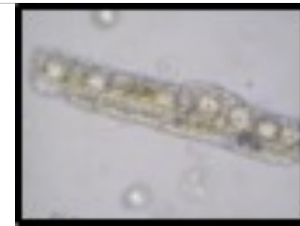

4.Fibre with starch grains

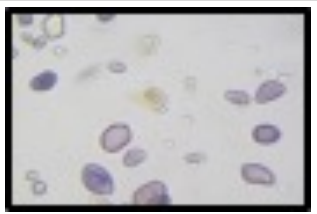

8.Iodine stained starch grains

Plate 5: Leaf petiole of T. malabarica

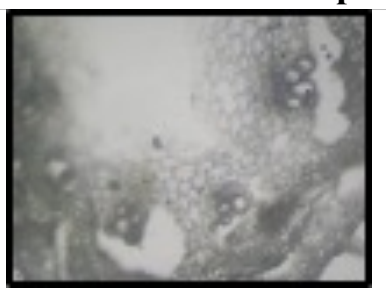

2. Pericycle, phloem and xylem

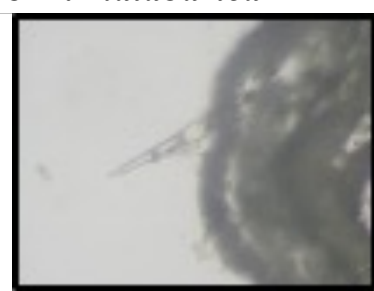

3.Epidermis with trichome

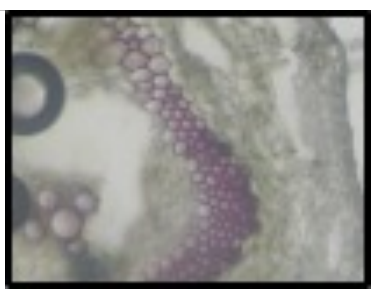

4.Lignified elementsPericycle, phloem and xylem

\section{Plate 6: Leaf Petiole of T.cordifolia}

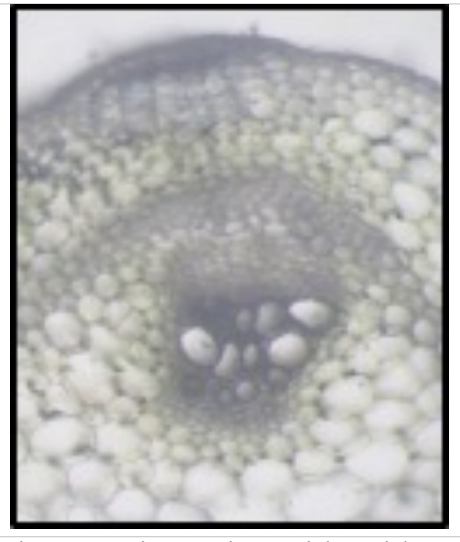

1.Diagramatic section with epidermis, cortex and vascular bundle

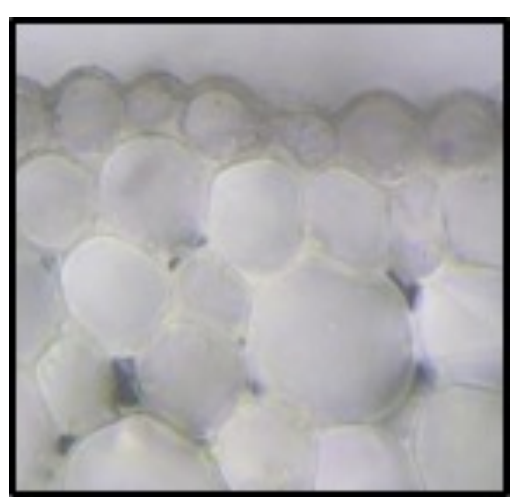

2.Epidermis with thick cuticle

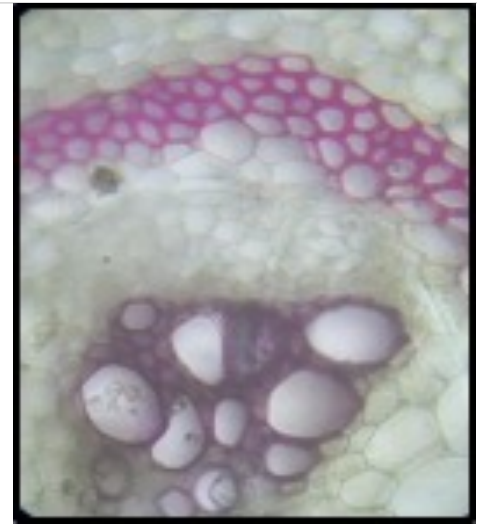

3.Pericycle, phloem and xylem 


\section{Plate 7: Through Midrib of T. malabarica}

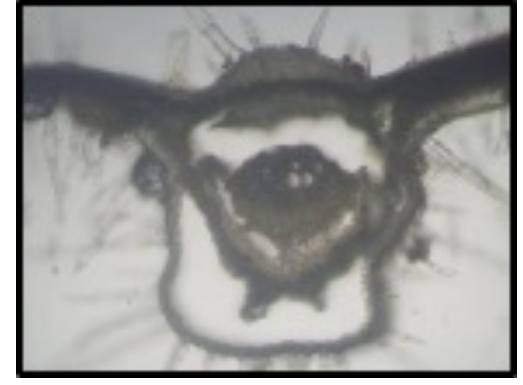

1. T.S. with upper and lower epidermis and central vascular bundle

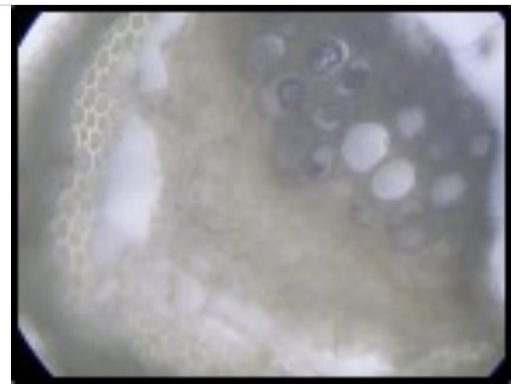

2. Vascular bundle with phloem and xylem

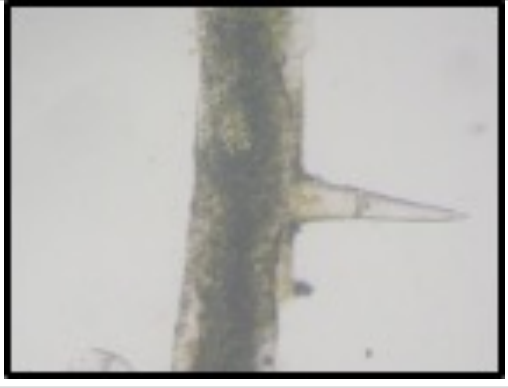

3.Upper epidermis with trichome

Plate 8: Through Midrib of T. cordifolia



1.T.S. with upper and lower epidermis and central vascular bundle

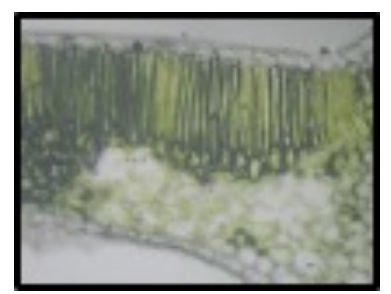

2.Upper palisade and lower spongy parenchyma

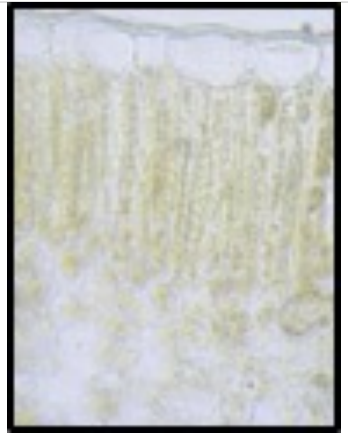

3.Upper epidermis with cuticle 4.Vascular bundle with phloem and palisade cells

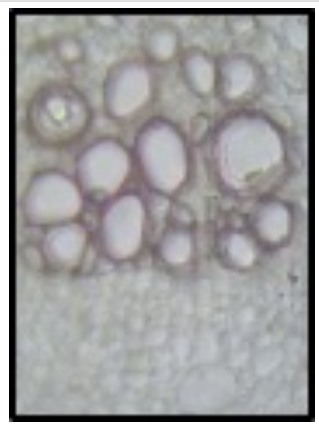

and xylem

Plate 9: Powder microscopy of T. malabarica leaf



1.Powder as such natural

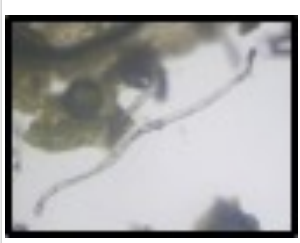

2.Simple fibre

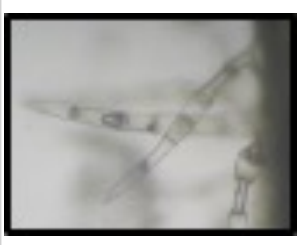

3.Simple and multicellular trichomes

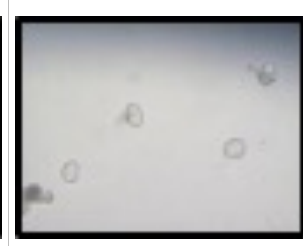

4.Oil globules

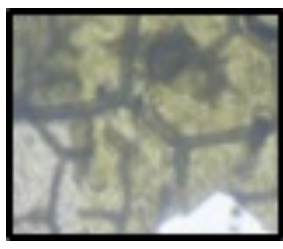

5.epidermal cells

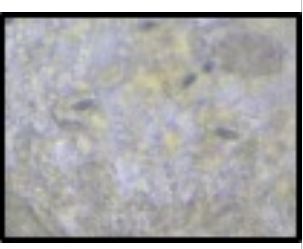

6.Epidermal cells with stomata

Plate 10: Powder microscopy of T. cordifolia leaf

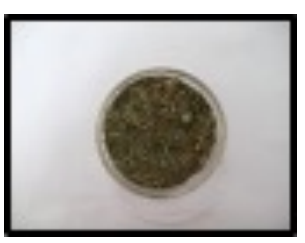

1.Natural powder as such

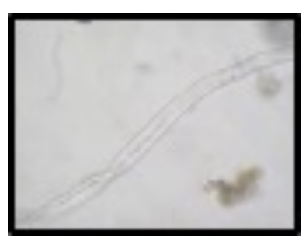

2.Simple fibre

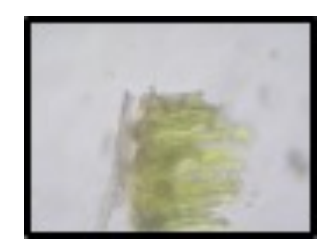

3.Fragment of palisade cells

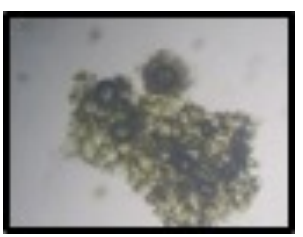

4.Fragment of spongy parenchyma



5.Epidermal cells

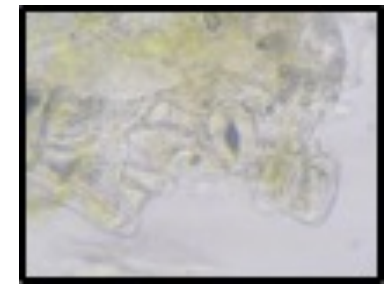

6.Epidermal cells with stomata



7.Multicellular trichome

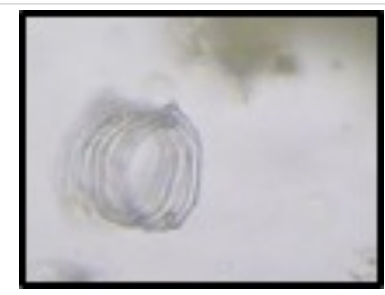

8.Annular vessels 


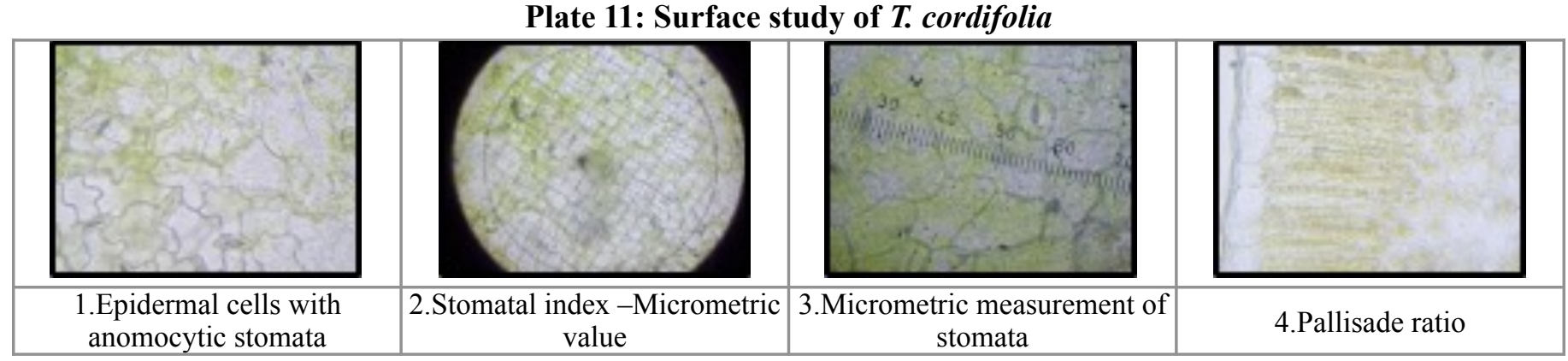

Plate 12: Surface study of T. malabarica leaf



1. Epidermal cells with anomocytic stomata

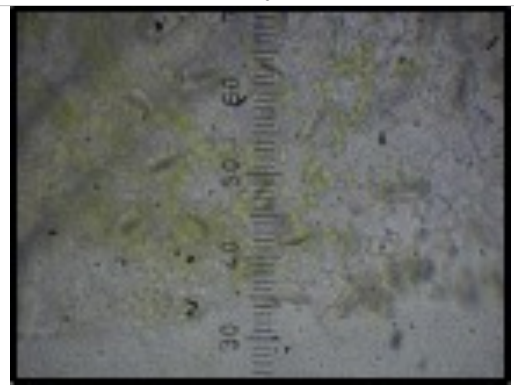

2. Micrometric measurement of stomata

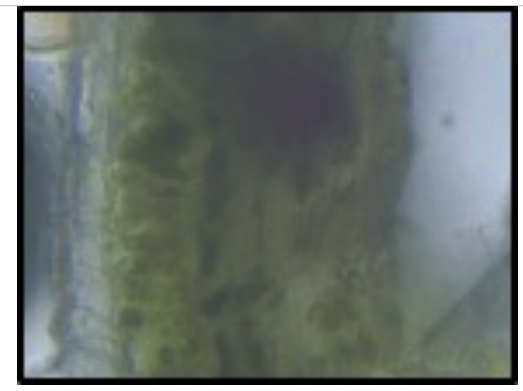

3. Palisade ratio

\section{References}

1. https://www.ayush.gov.in/docs/ayush-Protocolcovid-19.pdf dated 22/03/2021 time 13:05 IST

2. Anonymous. The Ayurvedic Pharmacopoeia of India. Part I. 1 ed. New Delhi; Department Of AYUSH; 2001. 70-71p.

3. Badani P, Vyas, H., Harisha, C. R, Shukla, V.J. Impact of Samskara on Guduchi and Guduchi Ghanavati. I J Ayu Pharm Chem;January, 2015; 4(3); 264-275p.

4. Noorunnisa Begum S, Patturaj R, Ravikumar K. Comparative pharmacognostical and histochemical studies on the three different species of Tinospora on stem and leaf. JPP; 2019; 8(2); 650-655p.

5. Saha. S. Ghosh, S. Tinospora cordifolia: one plant, many roles. Ancient Sci. Life; 2012; 3; 151-159p.
6. Serena K., Remashree A.B. Histological, Histochemical and Phytochemical Studies of the raw drug Amrita from different raw drug markets of Kerala. IJIMS; 2014; 1(5); 182-191p.

7. Junjarwad A.V et al. Pharmacognostical physicochemical and histochemical evaluation of brihat panchamoola churna. IJRAP; 2011; 2 (5); 1423-1426p.

8. Mukherjee P.K. Quality control of herbal drugs. 2nd Reprint ed. New Delhi;Buisness Horizons; 2007.164-165p.

9. Krishnamurthy K.V. Methods in the Plant Histochemistry. Madras; Vishwanandan Pvt.Limited; 1988. 1-77p.

10. Wallis TE. Textbook of pharmacognosy. $5^{\text {th }}$ ed. London; Churchill Publication; 1985. 